\title{
VOTE BUYING AND VICTORY OF ELECTION: THE CASE OF TAIWAN
}

\section{Chyi-Lu Jang, Chun-Ping Chang*}

\begin{abstract}
This paper examines the effect of vote buying on the vote shares of multiple parties using maximum likelihood estimation of a Dirichlet distribution in a panel of 23 counties of Taiwan over the period of 1998-2008. We find that vote buying significantly influences the vote shares of multiple parties in Taiwan parliamentary elections. In particular, we find that vote buying reduces the likelihood of Chinese National Party (KMT) and Democratic Progressive Party (DPP) votes by $10 \%$ and $11 \%$, respectively. Our results provide strong evidence that vote buying decreases the probability of electoral success. We conclude that vote buying does not ensure victory in Taiwan parliamentary elections, and, therefore, emphasize that vote buying is ineffective and counterproductive practice. We offer several possible explanations for why candidates use scarce resources for this illegal practice during election campaigns. These results are robust to group logit model with seemingly unrelated regressions.
\end{abstract}

Keywords: vote buying, vote shares, Dirichlet distribution, Taiwan

JEL Classification: D72, 053, P16

\section{Introduction}

Considerable amount of literature has been devoted to understanding the nature and significance of vote buying. Chu and Diamond (1999) argue that vote buying is "inconsistent with a culture of respect for law" and destabilizes "progress toward the consolidation and deepening of democracy” in Taiwan (p. 822). In addition, Hasen (2000) explains that vote buying contributes to a decrease in "overall social wealth because those who buy votes will do so in order to capture government subsidies (pp. 1332-1333).” Gersbach and Mühe (2011) thus emphasize that vote buying leads to the persistence of poverty. Further, Chu and Diamond (1999) assert that vote buying breeds corruption and bribery due to the nature of this illegal practice.

The literature documents that the illegal practice of vote buying is a fundamental component of voter mobilization in Taiwan (Bosco, 1994). For instance, Schaffer (2004) indicates that 27 per cent of voters in 1999 confirmed that they had received money in the past election campaigns. Similarly, Chu and Diamond (1999) suggest that vote buying was significantly ascending during the 1998 Legislative Yuan election in Taiwan. Further, Nathan (1993) indicates that the practice of vote buying was extensively used during the 1992 Taiwan election. However, due to the illegal nature of this phenomenon, vote buying has been difficult

* Chyi-Lu Jang, Department of Political Economy, National Sun Yat-Sen University, Kaohsiung, Taiwan, ROC (cjang@mail.nsysu.edu.tw);

Chun-Ping Chang, Department of Marketing Management, Shih Chien University, Kaohsiung, Taiwan, ROC, and Visiting Research Fellow, School of Economics and Finance, Xi' an Jiaotong University, Shaanxi, China. 
to measure precisely (Rigger, 2002; Wang and Kurzman, 2007). Nevertheless, several papers have attempted to empirically investigate the causes and nature of vote buying in Taiwan (see, for example, Rigger, 2002; Wu and Huang, 2004; Wang and Kurzman, 2007). ${ }^{1}$

Given the amount of research and discussion that this practice has received, many scholars question whether vote buying influences the outcome of election. For instance, Bosco (1994) asserts that "vote buying does not necessarily affect the outcome of election (p. 41)". Similarly, Wang and Kurzman (2007) indicate that the financial influence of vote buying in Taiwan is comparatively small. It is important to note that the fundamental purpose of vote buying is to "offer rewards in exchange for votes, with the ultimate goal of gaining office (Wu and Huang, 2004, p. 757)”. It is therefore critically important to understand the nature and significance of vote buying, especially if it affects the outcome of the election (Rigger, 2002). This is precisely the goal of the present paper. Our question is whether vote buying increases the likelihood of electoral success. More specifically, we ask, does vote buying ensure victory in an election?

We particularly apply this question for the case of Taiwan parliamentary elections. The process of political liberalization and democratization allowed Taiwan to experience consecutive elections. In the early 1990s, Taiwan was transformed from an authoritarian one-party state into a multi-party democracy, with the first parliamentary elections of the Legislative Yuan in 1992, the Taipei and Kaohsiung Mayors in 1994 and the President in 1996. ${ }^{2}$ Voter participation in recent elections has been remarkably different from the high levels of turnout prior to 1992. For instance, nearly 70 per cent of voters participated in the first parliamentary elections in 1992, approximately 65 per cent turnout in the early 2000s, and less than 60 per cent participated in 2008. This pattern in voter turnout is perhaps surprising given that democratic transition is observed in Taiwan.

We examine the impact of vote buying on vote shares of multiple parties using the parliamentary election data in 23 counties of Taiwan over the period of 1998-2008. ${ }^{3}$ We develop a model of vote shares where we simultaneously model multiple parties in our specification using a maximum likelihood estimation of a Dirichlet distribution. The Dirichlet specification is a suitable model for proportional data with more than two shares (Aitchison, 1986; Buis et al., 2006) where it enables us to concurrently estimate the vote shares of multiple parties and it constrains these estimated vote shares to a sum of one (Brehm et al., 1998, 2003; York and Munroe, 2010). To ensure further robustness of our results, we employ a group logit method with seemingly unrelated regression in the empirical analysis. The major advantage of group logit method with seemingly unrelated regression is to analyse multi-party, district-level aggregate election data (Mikhailov et al., 2002).Our study focus on Taiwan based on following reasons. In the beginning, scholars agree that vote buying is the most effective technique for political party to influence electoral outcome when Taiwan democratized in recently. A survey taken by Chao (1992), who point out to around 70 per cent of voters and 80 per cent of politicians admit the existence vote buying in Taiwan. Furthermore, previous wisdom also indicates that vote buying by candidates

\footnotetext{
1 In addition, Brusco et al. (2004) and Vicente (2007) examine vote buying in Argentina and Sao Tome and Principe, respectively.

2 Taiwan has two election categories at the central government level: the presidential elections and parliamentary elections of office for presidents and members of the legislature.

3 The counties are the highest ranking authorities below the national government because there are no states or administrative regions in Taiwan.
} 
is the primary tools of electoral mobilization then will affect election outcome (seeing as Wu and Huang, 2004; Wang and Kurzman, 2007). Though Rigger (2002) argues that vote buying attracted progressively increase attention from scholars, but researchers still do not offer the sufficient picture of vote buying functions in Taiwan's electoral process.

Hence, Taiwan is a democratic success story to show levels of party competition as well as civic engagement similar to those industrialized democracies (Ho et al., 2013). However, accompanying with an improvement of voters' educational level as well as the development of democracy in the islands, whether the vote buying still plays a critical factor to drive electoral choice in Taiwan and what the main implications we can catch in accordance with our empirical results? We believe that Taiwan provides an excellent test case for researchers to investigate these issues. In particular, our evidence find that vote buying reduces vote shares of both main political parties in Taiwan after a rigorous quantitative analysis, which not only lend the important reflections for other new democracies, but also offer a critical implication for those candidates who attempts to buy votes in the election, no matter at current or in the future.

Our results provide evidence that vote buying significantly influences the vote shares of multiple parties (Chinese National Party, KMT; and Democratic Progressive Party, DPP) in Taiwan parliamentary elections. In particular, we find that vote buying decreases the likelihood of KMT and DPP votes by $10 \%$ and $11 \%$, respectively. Our findings provide robust evidence that vote buying reduces the probability of electoral success. We conclude that vote buying does not ensure victory in Taiwan parliamentary elections, and, thus, emphasize that vote buying is ineffective and counter-productive practice. We offer several possible explanations for why candidates use scarce resources for this illegal practice during election campaigns.

The rest of the paper is organized as follows. In Section 2, we discuss the illegal practice of vote buying in Taiwan. Section 3 details the empirical methodology utilized in the analysis and describes the variables. Section 4 presents the empirical findings and conducts several sensitivity tests to confirm the robustness of our results. The final section summarizes the major findings and provides several potential explanations for why parties continue to utilize vote buying during election campaigns in Taiwan.

\section{Vote Buying in Taiwan}

Vote buying represents the exchange of money, gifts, goods or services for a vote. A "vote is literally 'bought' or 'sold' depending on whether one adopts the perspective of the candidate or the voter (Schaffer, 2002, p. 1)". The process of vote buying is accomplished via vote brokers, called the tiau-a-ka (Rigger, 2000). The vote brokers propose money, goods, or services to the voters in return for their vote (Wu and Huang, 2004). During the election movement, the vote brokers supply "large blocks of votes" to their respective candidates (Rigger, 2000, p. 144). Wu and Huang (2004) document a variety of vote buying techniques employed by vote brokers in Taiwan, i.e., utilization of money and gifts, procuring voters' documents, gambling on election outcome, removing loans, election dinners, raising workers' income, and reimbursing voters' tax fees. In addition, the critically important role of vote brokers is to persuade the voters that they "invested their votes profitably (Rigger, 2000, p. 144)".

Vote brokers utilize three approaches to induce individuals to vote or not to vote for a particular candidate: (a) instrumental, (b) normative and (c) coercive compliances (Schaffer, 2002). In what follows, we briefly describe these compliances, as detailed 
in Schafer (2002). The instrumental compliance suggests that voters alter or do not alter their electoral behaviour in exchange for substantial gifts. Normative compliance indicates that voters change or do not change their electoral behaviour due to sentiment of obligation or the proposal by the vote broker persuades the voter of the integrity, honesty, and merit of the candidate. In contrast, coercive compliance refers to vote brokers intimidating the voters to modify their electoral behaviour. Hence, voters fear of retaliation if they refuse the offer produced by the vote broker and if they do not vote as intended subsequently to the acceptance of the offer. Coercion compliances generally consist of "crude violence, threats of punishment, or the withdrawal of benefits that clients currently enjoy (Wang and Kurzman, 2007, p. 227)”.

The literature suggests that vote brokers employ several strategies to produce these types of compliances in Taiwan. For instance, vote brokers observe and examine the collective voter turnout of villages or neighbourhoods to generate instrumental or coercive compliances (Schaffer, 2002). This particular method is pertinent in circumstances where vote broker proposes gifts to entire villages or neighbourhoods (Schaffer, 20002). Hence, monitoring the aggregate voter turnout continues to transpire in Taiwan (Rigger, 2000). Nevertheless, coercion compliance was rarely utilized in voter mobilization during election campaigns in Taiwan (Wang and Kurzman, 2007). Further, vote brokers grant rewards that are distributed conditionally upon the appropriate candidate gaining office in Taiwan elections (Wu and Huang, 2004). For instance, Schaffer (2002) indicates that vote brokers utilized a betting system to generate financial enticements for individuals to vote for the KMT's presidential candidate in the election of 2000. In addition, vote brokers generally inspire voters that a particular candidate is commendable and admirable to produce normative compliance. This particular operation is achieved via gifts and money (Schaffer, 2002).

In addition, vote brokers critically establish, what Schaffer identifies as - "a sense of personal obligation" - to generate any type of compliances. This is accomplished when candidates employ vote brokers who are "respected members of their communities" to activate political support for their party (Schaffer, 2002, p. 6). Therefore, when vote brokers have a considerable social and economic status, it increases the probability that individuals would pursue their view (Wang and Kurzman, 2007). ${ }^{4}$ Further, candidates send their agents in areas where they would “otherwise receive no support (Bosco, 1994, p. 40)”. In summary, vote brokers may attempt to utilize a combination of different strategies and techniques to convince voters to change their electoral behaviour in Taiwan elections.

Finally, it is important to note that the judicial system was powerless to produce convictions in the vote buying cases because of political obstruction in Taiwan (Schaffer, 2004; Wu and Huang, 2004). Becker (1968) argued that the probability of committing a crime depends primarily on the probability of detection, apprehension, and the penalty imposed by the legal institution. Hence, the single most influential factor that can affect the level of illegal behaviour in a society is the probability that the illegal activity is discovered and the lawbreaker apprehended and convicted (Becker, 1968). As such, the deterrent value of the illegal widespread practice of vote buying critically rests on the ability and willingness of the legal system to enforce the rule of law. Hicken (2007) thus suggests that an institutional restructuring is critically important in order to challenge the vote buying process.

$4 \quad$ Khemani (2004) also discusses the process of vote buying in India, and suggests that citizens who have significant social standing in their communities can assemble votes for a candidate/party. 


\section{Model and Data}

\subsection{Model}

The Dirichlet votes shares model describes patterns of voting of different parties within a election campaign. It models simultaneously the counts of the number of votes of each party over a period of time, so that it describes voting tendency and party choice at the same time. The model also assumes that voters have an acknowledge of the partisan position, so that they are not influenced by previous voting behaviour and campaign strategies; for this reason, voter's characteristics and party's competition instruments are not included in the model. As the campaign is assumed to be competed, these effects are already incorporated in each party's vote share which influences vote share of other party which calculated by the model.

Suppose that party $j$ of the proportion of total votes on each election campaign $i$, denoted $y_{i j}$, by definition, then, both of the following steps:

$$
\begin{gathered}
y_{i j}>0, \quad \forall_{j}=1, \ldots, J \\
\sum_{j=1}^{J} y_{i j}=1
\end{gathered}
$$

Considering one main variant of compositional data analytic strategies, the Dirichlet, and each campaign is produced by an independent process. Suppose $y_{i j}^{*}$ represents the average vote shares in election campaign $i$ for different party $j$ and the probability density function for the gamma distribution is:

$$
\begin{aligned}
& y_{i j}^{*}=f_{r}\left(y_{i j}^{*} \mid v_{j}\right) \\
= & y_{i j}^{v_{j-1}} \frac{\exp \left(-y_{i j}\right)}{\Gamma\left(v_{j}\right)}
\end{aligned}
$$

$v_{j}$ is the mean and variance for the gamma pdf and the shape parameters are integer the distribution is also known as the Erlang distribution. The vote shares of each party are distributed according to a Dirichlet distribution:

$$
\begin{gathered}
\left(y_{1}, \ldots, y_{J}\right)=f_{D}\left(Y_{1}, \ldots, Y_{J} \mid v_{1}, \ldots, v_{J}\right) \\
=\frac{\Gamma\left(\sum_{k=0}^{J} v_{k}\right)}{\prod_{k=0}^{J} \Gamma\left(v_{k}\right)} \prod_{k=1}^{J} y_{k}^{v_{k-1}} \\
v_{j}>0, \quad \forall_{j}=1, \ldots, J
\end{gathered}
$$

we can reparameterize the $v_{j}$ in terms of explanatory variables and coefficients with simple exponentiation.

$$
\alpha_{j}=\exp \left(X \beta_{j}\right)
$$

where the effect parameters $\beta_{j}$ vary by party and the $X$ is the same set of explanatory variables. If one assumes that the observations are distributed identically and independently, then the log-likelihood for the reparameterized Dirichlet is: 


$$
\ln L(\beta \mid X, y)=\sum_{i=1}^{N}\left[\ln \Gamma\left(\sum_{j=1}^{J} e^{X \beta_{j}}\right)+\sum_{j=1}^{J} e^{X \beta_{j}} \ln y_{j}-\sum_{j=1}^{J} \ln \Gamma\left(e^{X \beta_{j}}\right)\right]
$$

the log likelihood is optimized with a statistical package as Gauss for the reparameterized Dirichlet under the observations are distributed identically and independently:

Based on the previous model, we develop a model of vote shares in 23 counties of Taiwan from 1998 to 2008 for two major parties (Chinese National Party, KMT; and Democratic Progressive Party, DPP) using a maximum likelihood estimation of a Dirichlet distribution. In our multivariate Dirichlet specification, we estimate a model of KMT and DPP vote shares relative to the reference category - other party. The other party represents the candidates that are nominated by New Party (NP) and People First Party (PFP). The expected vote shares are expressed as equation (5), (6), (8) as follows:

$$
p_{i t}^{j}=\left(p_{i t}^{K M T}, p_{i t}^{D P P}, p_{i t}^{\text {OTHER }}\right) \quad \text { where } p_{i t}^{j} \geq 0 \text { and } \sum_{j}^{n} p_{i t}^{j}=1
$$

$j=\mathrm{KMT}$, DPP, Other; $p_{i t}^{j}$ is the probability that party $j$ is chosen relative to a comprehensive set of possible votes: KMT, DPP, and other; $i$ and $t$ represent county and time period, respectively. Party votes are assigned to three categories within each 23 counties of Taiwan: KMT, DPP and other party. Also, as can be seen, the total shares of votes are constrained to sum to one. ${ }^{5}$ The Dirichlet model enables us to simultaneously estimate the vote shares of KMT and DPP parties relative to the reference category - other party. We use Buis et al. (2006) Stata module to estimate our multivariate Dirichlet vote shares model.

\subsection{Data}

The analysis is based upon data recorded over the 1998-2008 period, covering 23 counties of Taiwan. Taiwan experienced parliamentary elections in 1998, 2001, 2004 and 2008 following the re-establishment of democracy in $1992 .{ }^{6}$ The dependent variable is the vote shares for candidates of individual parties in a particular year $t$ (election) and county $i{ }^{7}$ The data for vote shares comes from the Central Election Commission of Taiwan. The data for all the explanatory variables are obtained from the National Statistics of Taiwan - Key Economic and Social Indicators for Local Government. The summary statistics and data source for all the variables are displayed in Table 1.

5 For a detailed discussion on the Dirichlet model, see Aitchison (1986), Brehm et al. (1998; 2003), and more recently, York and Munroe (2010).

6 The term of the parliamentary had been amended from three to four years in 2008. Taiwan practiced a single non-transferable vote (SNTV) in a multi-member district during the 1998, 2001, and 2004 elections. The SNTV electoral system is subject to more vote buying cases than other systems (Hicken, 2007). Hence, Taiwan switched to a single-member district voting electoral system in 2008 elections. This system takes advantage of split-ticket voting, which is intended to reduce vote buying during election campaigns.

$7 \quad$ Vote share $=$ total votes for candidate/eligible voters. 
Table 1 | Descriptive Statistics

\begin{tabular}{|l|r|r|r|r|}
\hline Variables & \multicolumn{1}{c|}{ Mean } & St. dev. & Minimum & Maximum \\
\hline KMT & 0.403 & 0.159 & 0.000 & 0.717 \\
\hline DPP & 0.334 & 0.099 & 0.000 & 0.555 \\
\hline Other & 0.263 & 0.170 & 0.000 & 0.726 \\
\hline Vote buying & 1.554 & 1.787 & 0.000 & 8.000 \\
\hline Closeness & 14.177 & 11.559 & 0.310 & 44.104 \\
\hline Magnitude & $1,565.486$ & $1,331.654$ & 60.026 & $4,628.571$ \\
\hline Density & $2,177.803$ & $2,862.504$ & 65.960 & $9,933.040$ \\
\hline Stability & 3.558 & 8.387 & -18.710 & 30.970 \\
\hline Homogeneity & 1.474 & 0.434 & 1.000 & 3.050 \\
\hline Education & 24.542 & 9.802 & 7.960 & 57.190 \\
\hline Income & $233,003.228$ & $43,537.094$ & $163,308.740$ & $386,881.790$ \\
\hline
\end{tabular}

Note: "Vote buying" is calculated by authors.

Source:

1. The data for vote shares: KMT, DPP and Other are from the Central Election Commission of Taiwan.

2. All the explanatory variables are obtained from the National Statistics of Taiwan - Key Economic and Social Indicators for Local Government.

Rigger (2002) and Wang and Kurzman (2007) emphasize that it is difficult to precisely measure vote buying due to the illegal nature of this practice. Vote buying is significantly associated with corruption (Chu and Diamond, 1999; Vicente, 2010). The literature has employed the number of government officials who have been convicted for corrupt activities in each state to proxy for corruption in the United States (see, for example, Fisman and Gatti, 2002; Glaeser and Saks, 2006). Further, Wu and Huang (2004) used the number of "defendants in vote-buying cases" to measure vote buying in Taiwan (p. 760). As such, we quantify vote buying as the number of candidates in each county who have been prosecuted for vote buying by the court in accordance with the law. ${ }^{8}$

8 Nevertheless, one referee mentions us that the prosecuted candidates in vote-buying cases may be found innocence after the court's judgments, which, in turn, suggest that a biased estimation would be delivered because using the "suspected cases" but not the "determined judgment". We reply referee's concerns from following aspects: Firstly, due to the judiciary which includes the prosecution and court systems in Taiwan, while citizens gain information of vote buying in the campaigns period from the prosecutors' investigation as their voting decisions for candidates selected (Kerr, 2013), we believe that it is not suitable, in general, based on the court's final judgment in a few years later after the election. Secondly, likewise, Greene (2002) proposes that regression tool allow us to predict about past, present, or future events in accordance with information as past or present events. In such way, while the vote shares of political parties are commonly responding to a mix of economic and noneconomic determined (Lewis-Beck and Stegmaier, 2000), in particular, researchers cannot use the "future information" - the vote-buying verdicts which judged by the court with three trials after a long period, to predict the present 
To obtain efficient estimation results, we incorporate additional explanatory variables based on the literature on the determinants of voter turnout. The literature documents that the closeness of an election is considerably associated with voter turnout (Cox and Munger, 1989; Frank et al., 2004). Matsusaka and Palda (1993) suggest that “as a person's probability of casting a vote which swings the election increases, he/she becomes more likely to vote (p. 856).” In other words, the general public is more likely to vote in a close race because they expect to change the result of an election (Cox and Munger, 1989). This is because citizens believe that there is a high likelihood that their vote will influence the outcome in a close election (Kostadinova, 2003). To capture the electoral competition (closeness) in an election, we use the difference in the vote shares of the two strongest parties.

Further, the process of voting is costly (Downs, 1957). Niemi (1976) indicates that higher costs of voting may considerably lower voter turnout in an election. That is, voters are more likely to participate in an election if they experience lower costs with voting (Colomer, 1991; Lehoucq and Wall, 2004). For instance, Haspel and Knotts (2005) argue that "the distance one must travel in order to vote" contributes to lower voter turnout (p. 561). We employ the number of square kilometers in a county to proxy for magnitude.

In addition, Geys (2006) explains that population concentration may lower voter turnout because (1) "cities are more individualistic in nature such that there is less 'social pressure' to turn out and cast a vote" and (2) citizens are less likely to know all the candidates, parties and their respective policies (p. 643). As regards the former point, Harbaugh (1996) shows that citizens vote in an election as they enjoy receiving "praise" from other citizens. For the latter point, Feddersen and Pesendorfer (1996) show that citizens would rather refrain from voting when they are not knowledgeable about the qualities of the candidates in an election. We use the ratio of a population to a square kilometer to represent population density.

Geys (2006) also argues that population stability may improve voter turnout because citizens living in the same region for an extended episode (1) may potentially enhance their awareness and understanding of candidates and their policies, and (2) generate "feelings of identification and group solidarity” to participating in an election (p. 644). ${ }^{9}$ For instance, Hillman (2010) indicates that the "decision whether to vote depends on whether there is a candidate sufficiently close to the individual's expressive ideal (p. 416)." ${ }^{10}$ Similarly, population movement may potentially reduce voter turnout: citizens will not participate in an election because they believe they may migrate, and, therefore, will not be influenced by the actions of the candidates (Geys, 2006). We use the population growth rate to measure population stability.

vote shares of political parties. Finally, since the prosecuted candidates who were investigated by prosecution usually keep high conviction justice in the court recently, once the vote buying is difficult to measure accurately because of illicit behaviours (Cox and Kousser 1981; Rigger, 2002), we thus believe that it is reasonable to use the prosecuted candidates as a measure of vote buying in our investigations. We are grateful to one anonymous referee who suggested this possibility.

9 Bellettini (1998) argues that present policies may not impact the likelihood of an electoral victory. Elinder (2010), however, finds that citizens hold the government accountable for the domestic economic conditions (economic growth and employment) because it determines how they vote in an election for the case of Sweden. This is the case as larger voter turnout may suggest that citizens are holding the government accountable for current policies (Geys et al., 2010) and is the mechanism via which "forms of government" influence economic policy outcomes (Fumagalli and Narciso, 2012).

10 See Hillman (2010) for a detailed discussion on expressive behaviour (e.g. expressive voting). 
In addition, greater level of “socio-economic, racial, or ethnic homogeneity” generates political participation in a society, and, thus, leads to higher voter turnout in an election (Geys, 2006, p. 644). We use the ratio of population to public officials to proxy for homogeneity. The literature also suggests that the level of education and income is a critically important determinant of voter turnout (Verba and Nie, 1972; Castanheira, 2003; Lehoucq and Wall, 2004; Sobbrio and Navarra, 2010; Hortala-Vallve and Esteve-Volart, 2011). Voter turnout is rather positively associated with the level of education and income (Lijphart, 1997; Lehoucq and Wall, 2004). ${ }^{11}$ For instance, Bellettini (1998) explains that voter's income influences the outcome of an election. To capture the level of income and education, we use per capita disposable income and the ratio of population over the age of 15 with college level education, respectively.

\section{Empirical Results}

We simultaneously estimate the vote shares of KMT and DPP parties relative to the reference category - other party. Table 2 displays the estimation results of multivariate Dirichlet vote shares model for KMT and DPP parties. The coefficients in Table 2 demonstrate the effect of the independent variables on the change in the likelihood that a county will have more or less KMT or DPP votes relative to the reference category - other party. The statistical significance of a coefficients denote the degree to which the corresponding independent variables influence the change in the likelihood that a county will have more or less KMT or DPP votes compared to the reference category - other party.

Table 2 | Multivariate Dirichlet Vote Shares Model: Full Sample

\begin{tabular}{|l|c|c|}
\hline & KMT/Other & DPP/Other \\
\hline Constant & $-1.441^{*}(-1.885)$ & $-0.973(-1.250)$ \\
\hline Vote buying & $-0.100^{* *}(-2.305)$ & $-0.110^{* *}(-2.445)$ \\
\hline Closeness & $0.036^{* *}(5.148)$ & $0.014^{*}(1.900)$ \\
\hline Magnitude & $0.012(1.204)$ & $0.016(1.520)$ \\
\hline Density & $-0.013^{* *}(-2.488)$ & $-0.008(-1.541)$ \\
\hline Stability & $-0.016(-1.111)$ & $-0.025^{*}(-1.702)$ \\
\hline Homogeneity & $0.174(0.523)$ & $-0.030(-0.085)$ \\
\hline Education & $0.042^{* *}(2.335)$ & $0.043^{* *}(2.376)$ \\
\hline Income & $0.031(0.754)$ & $0.023(0.564)$ \\
\hline
\end{tabular}

Note: The t-statistics are in parentheses. ${ }^{* *}$ and * indicates the statistical significance at the $5 \%$ and $10 \%$ level, respectively.

Source: Own estimation based on data from the National Statistics of Taiwan - Key Economic and Social Indicators for Local Government and the Central Election Commission of Taiwan.

11 Castanheira (2003), however, notes that wealthier citizens may have larger opportunity cost of time, and, thus, experience larger costs associated with voting, thereby generating lower voter turnout.

In contrast, Sobbrio and Navarra (2010) find that voters earn greater income as compared to non-voters in the analysis of 14 European countries. 
To start, the variable vote buying has a negative and statistically significant coefficient at the 5\% level in both models, suggesting that vote buying reduces the likelihood of KMT and DPP votes by about $10 \%$ and $11 \%$, respectively. Our results are broadly consistent with those of Bratton (2008), who suggests that vote buying does not work for the case of Nigeria. Our findings also generally support the notion that vote buying is not critically important in determining the outcome of an election in Taiwan, as documented by Jacobs (1980), Bosco (1994) and Tien and Chu (1996). In fact, our results indicate that vote buying reduces the probability of electoral success.

Next, consider the effect of the controlled variables. As expected, the variable closeness is positive and statistically significant for both models, indicating that close elections increase the probability of KMT and DPP votes by approximately $3.6 \%$ and $1.4 \%$, respectively. This effect, however, appears less strong for the DPP specification. Further, the variable density has the anticipated negative and statistically significant coefficient at the $5 \%$ level in the KMT model, suggesting that densely populated areas decrease the likelihood of KMT votes by about $1.3 \%$. This effect, however is statistically insignificant at the conventional levels in the DPP model.

In addition, population stability has a negative and statistically significant coefficient for the DPP model, implying that higher population growth rates reduce the probability of DPP votes by about $2.5 \%$. This effect however is statistically insignificant in the KMT specification. Education has the expected effect, indicating that higher levels of education increase the likelihood of KMT and DPP votes by approximately $4.2 \%$ and $4.3 \%$, respectively. Finally, it appears that the variables magnitude, homogeneity and income have limited impact on vote shares, which is evident from the insignificant coefficients in both models.

Table 3 | Multivariate Dirichlet Vote Shares Model: 1998 and 2001 Elections

\begin{tabular}{|l|c|c|}
\hline & KMT/Other & DPP/Other \\
\hline Constant & $1.782^{* *}(2.076)$ & $1.639^{*}(1.926)$ \\
\hline Vote buying & $-0.081^{* *}(-1.986)$ & $-0.084^{* *}(-1.972)$ \\
\hline Closeness & $0.022^{* *}(3.067)$ & $-0.004 \quad(-0.450)$ \\
\hline Magnitude & $-0.007 \quad(-0.698)$ & $-0.003 \quad(-0.339)$ \\
\hline Density & $-0.003^{* *}(-2.544)$ & $0.004 \quad(0.672)$ \\
\hline Stability & $0.001 \quad(0.032)$ & $-0.005 \quad(-0.360)$ \\
\hline Homogeneity & $0.031(0.110)$ & $-0.022 \quad(-0.070)$ \\
\hline Education & $-0.034(-1.357)$ & $-0.013 \quad(-0.511)$ \\
\hline Income & $-0.041 \quad(-0.859)$ & $-0.047 \quad(-0.989)$ \\
\hline
\end{tabular}

Source: Own estimation based on data from the National Statistics of Taiwan - Key Economic and Social Indicators for Local Government and the Central Election Commission of Taiwan.

To ensure the robustness of our results, we conduct several sensitivity tests. First, we examine whether the effect of vote buying on vote shares are sensitive to different time periods (elections). More specifically, we restrict our sample to the 1998 and 2001 elections 
(in Table 3), and 1998 and 2008 elections (in Table 4). As before, we simultaneously estimate the vote shares models of KMT and DPP parties relative to the reference category (other party) via maximum likelihood estimation of a Dirichlet distribution. As can be seen, the variable vote buying is negative and statistically significant at the $5 \%$ level in both models in Tables 3 and Table 4. These results again provide evidence that vote buying negatively impacts the vote shares of KMT and DPP parties.

Table 4 | Multivariate Dirichlet Vote Shares Model: 1998 and 2008 Elections

\begin{tabular}{|l|c|c|}
\hline & KMT/Other & DPP/Other \\
\hline Constant & $-1.594 \quad(-1.178)$ & $-1.824 \quad(-1.319)$ \\
\hline Vote buying & $-0.126^{* *}(-1.993)$ & $-0.130^{* *}(-1.960)$ \\
\hline Closeness & $0.015^{*}(1.805)$ & $-0.009 \quad(-0.979)$ \\
\hline Magnitude & $-0.005 \quad(-0.406)$ & $-0.005 \quad(-0.373)$ \\
\hline Density & $-0.018^{* *}(-2.701)$ & $0.021^{* *}(-2.946)$ \\
\hline Stability & $-0.027 \quad(-1.361)$ & $-0.030 \quad(-1.454)$ \\
\hline Homogeneity & $0.138 \quad(0.334)$ & $0.123 \quad(0.278)$ \\
\hline Education & $0.040^{* *}(2.321)$ & $0.049^{* *}(2.553)$ \\
\hline Income & $0.100 \quad(1.301)$ & $0.107 \quad(1.365)$ \\
\hline
\end{tabular}

Source: Own estimation based on data from the National Statistics of Taiwan - Key Economic and Social Indicators for Local Government and the Central Election Commission of Taiwan.

The remaining results are mostly in line with our full sample specification. There are however a few exceptions. For instance, notice that the variable education is statistically insignificant at the conventional levels for both models in Table 3 (1998 and 2001 elections). Nevertheless, this effect is statistically significant at the 5\% level in Table 4 (1998 and 2008 elections). It appears therefore that the level of education is not robustly associated with voter turnout. Further, the variables closeness is no longer statistically significant at the conventional levels for the DPP model in Tables 3 and Table 4.

Next, we re-examine the effect of vote buying on vote shares of multiple parties via a group logit method with seemingly unrelated regression, originally developed by Theil (1970) and recently modified to integrate seemingly unrelated regression by Mikhailov et al. (2002). We employ a different methodology to further demonstrate and ensure the robustness of our results. These results are displayed in Table 5. Notice that the variable vote buying continues to display a negative and statistically significant coefficient for KMT and DPP models, although this effect is statistically insignificant in the 2004 election for both parties. These results support our earlier findings: vote buying detriments the vote shares of KMT and DPP parties. Overall, our findings continue to indicate that vote buying decreases the probability of electoral success in Taiwan parliamentary elections. 
Table 5 | Group Logit Method with Seemingly Unrelated Regression

\begin{tabular}{|c|c|c|c|c|c|c|c|c|c|c|}
\hline & \multicolumn{2}{|c|}{ Full Sample } & \multicolumn{2}{|c|}{1998} & \multicolumn{2}{|c|}{2001} & \multicolumn{2}{|c|}{2004} & \multicolumn{2}{|c|}{2008} \\
\hline & KMT & DPP & KMT & DPP & KMT & DPP & KMT & DPP & KMT & DPP \\
\hline Constant & $\begin{array}{l}11.142 \\
(1.122)\end{array}$ & $\begin{array}{l}10.125 \\
(1.030)\end{array}$ & $\begin{array}{l}-13.588 \\
(-0.520)\end{array}$ & $\begin{array}{l}-15.263 \\
(-0.525)\end{array}$ & $\begin{array}{c}6.920 \\
(0.506)\end{array}$ & $\begin{array}{l}4.891 \\
(0.419)\end{array}$ & $\begin{array}{l}19.714^{*} \\
(1.783)\end{array}$ & $\begin{array}{l}13.479 \\
(1.274)\end{array}$ & $\begin{array}{c}-92.594^{* *} \\
(-2.935)\end{array}$ & $\begin{array}{l}-93.377^{*} \\
(-2.891)\end{array}$ \\
\hline Vote Buying & $\begin{array}{l}-0.138^{* *} \\
(-3.736)\end{array}$ & $\begin{array}{l}-0.114^{* *} \\
(-3.157)\end{array}$ & $\begin{array}{l}-0.113^{*} \\
(-1.931)\end{array}$ & $\begin{array}{l}-0.143^{* *} \\
(-2.098)\end{array}$ & $\begin{array}{l}-0.053^{* *} \\
(-2.063)\end{array}$ & $\begin{array}{l}-0.073^{* *} \\
(-2.546)\end{array}$ & $\begin{array}{c}0.090 \\
(1.361)\end{array}$ & $\begin{array}{c}-0.015 \\
(-0.266)\end{array}$ & $\begin{array}{l}-0.112^{* *} \\
(-2.500)\end{array}$ & $\begin{array}{l}-0.042^{* *} \\
(-2.187)\end{array}$ \\
\hline Closeness & $\begin{array}{l}0.031^{* *} \\
(5.220)\end{array}$ & $\begin{array}{c}0.009 \\
(1.474)\end{array}$ & $\begin{array}{l}0.019^{* *} \\
(2.327)\end{array}$ & $\begin{array}{c}-0.007 \\
(-0.798)\end{array}$ & $\begin{array}{c}-0.015 \\
(-0.854)\end{array}$ & $\begin{array}{c}0.006 \\
(0.376)\end{array}$ & $\begin{array}{c}0.009 \\
(0.717)\end{array}$ & $\begin{array}{l}0.036^{* *} \\
(3.180)\end{array}$ & $\begin{array}{c}-0.005 \\
(-0.223)\end{array}$ & $\begin{array}{c}-0.022 \\
(-0.953)\end{array}$ \\
\hline Magnitude & $\begin{array}{l}0.450^{* *} \\
(3.466)\end{array}$ & $\begin{array}{l}0.400^{* *} \\
(3.081)\end{array}$ & $\begin{array}{c}0.318 \\
(1.449)\end{array}$ & $\begin{array}{c}0.413^{*} \\
(1.653)\end{array}$ & $\begin{array}{c}0.069 \\
(0.362)\end{array}$ & $\begin{array}{c}0.200 \\
(1.075)\end{array}$ & $\begin{array}{c}0.142 \\
(0.777)\end{array}$ & $\begin{array}{l}0.438^{* *} \\
(2.530)\end{array}$ & $\begin{array}{c}0.007 \\
(0.017)\end{array}$ & $\begin{array}{c}-0.123 \\
(-0.283)\end{array}$ \\
\hline Density & $\begin{array}{c}0.227 \\
(1.595)\end{array}$ & $\begin{array}{c}0.216 \\
(1.484)\end{array}$ & $\begin{array}{l}0.413^{*} \\
(1.742)\end{array}$ & $\begin{array}{c}0.531^{*} \\
(1.889)\end{array}$ & $\begin{array}{c}0.064 \\
(0.260)\end{array}$ & $\begin{array}{c}0.211 \\
(0.845)\end{array}$ & $\begin{array}{c}-0.159 \\
(-0.738)\end{array}$ & $\begin{array}{c}0.080 \\
(0.393)\end{array}$ & $\begin{array}{c}0.446 \\
(0.917)\end{array}$ & $\begin{array}{c}0.274 \\
(0.560)\end{array}$ \\
\hline Stability & $\begin{array}{c}0.013 \\
(1.283)\end{array}$ & $\begin{array}{c}0.003 \\
(0.368)\end{array}$ & $\begin{array}{c}-0.014 \\
(-0.694)\end{array}$ & $\begin{array}{c}-0.017 \\
(-0.784)\end{array}$ & $\begin{array}{c}-0.016 \\
(-0.713)\end{array}$ & $\begin{array}{l}-0.017 \\
(-1.173)\end{array}$ & $\begin{array}{l}0.044^{* *} \\
(2.718)\end{array}$ & $\begin{array}{c}0.020 \\
(1.398)\end{array}$ & $\begin{array}{l}-0.062^{*} \\
(-1.717)\end{array}$ & $\begin{array}{l}-0.088^{* *} \\
(-2.552)\end{array}$ \\
\hline Homogeneity & $\begin{array}{l}-0.376 \\
(-1.476)\end{array}$ & $\begin{array}{l}-0.270 \\
(-1.132)\end{array}$ & $\begin{array}{c}-0.242 \\
(-0.671)\end{array}$ & $\begin{array}{c}-0.246 \\
(-0.629)\end{array}$ & $\begin{array}{c}-0.171 \\
(-0.246)\end{array}$ & $\begin{array}{c}-0.290 \\
(-0.676)\end{array}$ & $\begin{array}{l}1.030^{*} \\
(1.756)\end{array}$ & $\begin{array}{l}0.071^{*} \\
(0.166)\end{array}$ & $\begin{array}{c}-0.528 \\
(-0.574)\end{array}$ & $\begin{array}{c}-1.003 \\
(-1.228)\end{array}$ \\
\hline Education & $\begin{array}{l}0.033^{* *} \\
(1.991)\end{array}$ & $\begin{array}{l}0.030^{*} \\
(1.781)\end{array}$ & $\begin{array}{c}-0.042 \\
(-0.889)\end{array}$ & $\begin{array}{c}-0.046 \\
(-0.880)\end{array}$ & $\begin{array}{c}-0.017 \\
(-0.625)\end{array}$ & $\begin{array}{c}-0.009 \\
(-0.332)\end{array}$ & $\begin{array}{l}0.044^{* *} \\
(1.977)\end{array}$ & $\begin{array}{l}0.052^{* *} \\
(2.327)\end{array}$ & $\begin{array}{c}-0.079 \\
(-1.190)\end{array}$ & $\begin{array}{l}-0.069 \\
(-1.017)\end{array}$ \\
\hline Income & $\begin{array}{c}-1.291 \\
(-1.482)\end{array}$ & $\begin{array}{c}-1.170 \\
(-1.348)\end{array}$ & $\begin{array}{c}0.837 \\
(0.371)\end{array}$ & $\begin{array}{c}0.866 \\
(0.346)\end{array}$ & $\begin{array}{c}-0.575 \\
(-0.474)\end{array}$ & $\begin{array}{c}-0.566 \\
(-0.552)\end{array}$ & $\begin{array}{l}-1.819^{*} \\
(-1.802)\end{array}$ & $\begin{array}{c}-1.513 \\
(-1.557)\end{array}$ & $\begin{array}{l}7.621^{* *} \\
(2.714)\end{array}$ & $\begin{array}{l}7.878^{* *} \\
(2.735)\end{array}$ \\
\hline $\mathbf{R}^{2}$ & \multicolumn{2}{|c|}{0.384} & \multicolumn{2}{|c|}{0.787} & \multicolumn{2}{|c|}{0.570} & \multicolumn{2}{|c|}{0.619} & \multicolumn{2}{|c|}{0.833} \\
\hline
\end{tabular}

Source: Own estimation based on data from the National Statistics of Taiwan - Key Economic and Social Indicators for Local Government and the Central Election Commission of Taiwan.

\section{Conclusion and Discussion}

We examine the effect of vote buying on vote shares of multiple parties in Taiwan parliamentary elections. We find that vote buying is significantly associated with lower vote shares of KMT and DPP parties. Our findings provide evidence that vote buying does not ensure victory in Taiwan parliamentary elections. If vote buying is truly ineffective and counter-productive, our results raise a critically important question - why would candidates/parties use scarce resources for this illegal practice? This question is beyond the natural determinants captured by our estimated model, and we plan to further investigate this question in our future research. In the meantime, we offer several possible explanations.

To start, vote buying may generate inefficient and ineffective outcome in an election because voters may not change their electoral behaviour in exchange for substantial gifts. This is because voters would rather express support for their preferred candidate in an election (Hortala-Vallve and Esteve-Volart, 2011). In fact, Wang and Kurzman (2007) find that 45.4 per cent or more of the voters who sold their votes to the KMT failed to vote for the KMT's candidate in the 1993 Taiwan elections. ${ }^{12}$ Similarly, Bratton (2008) finds that 42

12 This was the case because clientelistic mobilization experienced four significant barriers: scarcity of vote brokers, inefficient and ineffective integration of local factions, embezzlement by vote brokers and local factions from the vote buying funds, and monetary constraints (Wang and Kurzman, 2007). 
per cent of voters would accept cash, however, vote based on their conscience in the 2007 general election campaign in Nigeria. Further, Houser et al. (2011) argue that coercing uninterested citizens to vote may generate an inefficient result. ${ }^{13}$

Next, the Taiwanese government commenced an enormous publicity campaign to reduce vote buying prior to the 2001 elections (Schaffer, 2004). For instance, the DPP immensely promoted "true democracy, clean government, national identity, and Taiwanese ethnicity” during the election campaigns (Wang and Kurzman, 2007, p. 229). As such, the general public did not support candidates who bought votes as a means to win elections. For instance, Chen Shui-bian, the DPP leader, defeated the KMT presidential candidate in the 2000 election because of his pledge to fight political corruption. The citizens of Taiwan supported Chen Shui-bian, which was evident by his victory in the presidential election. This was also the case in the 2007 general election campaign in Nigeria where the population denounced vote buying (Bratton, 2008).

Further, we presume that it is possible that candidates/parties might potentially believe that vote buying is generally an ineffective practice. This, however, raises the question of whether candidates/parties who could win easily without buying votes would resort to vote buying. As such, it might be reasonable to conclude that candidates/parties who need to engage in the practice of vote buying can be anticipated to do worse than those who do not need to buy votes. Conversely, we understand that this might not mean that vote buying is an ineffective and counter-productive practice. Thus, candidates/parties who buy votes may do better than they would have done in the absence of vote buying, but not well enough to succeed in an election.

Finally, it is possible that vote buying is rather effective and beneficial, however, the candidates for whom vote buying works best are also those against whom complaints are not made. For instance, Wu and Huang (2004) argue that the common practice of vote buying during an election campaign in Taiwan is the result of the judicial system. The judicial system was incapable to rigorously scrutinize vote buying cases because a great number of candidates were associated with the ruling party (Wu and Huang, 2004). Schaffer (2004) also indicates that the judicial system investigated a considerable amount of vote buying cases in Taiwan, however, produced only few convictions due to political hindrance. ${ }^{14}$

While vote buying is intended to benefit the candidates/parties to gain office, we find that this practice negatively impacts the vote shares of KMT and DPP parties. Our results are best summarized by Tien and Chu (1996), who argue that the practice of vote buying "no longer guaranteed electoral success (p. 1164)”. It is paradoxical that the illegal practice to offer rewards in exchange for votes, in turn, compromises the candidate/parties from winning elections. We conclude that vote buying reduces the probability of electoral success, and, therefore, emphasize that vote buying is ineffective and counter-productive practice.

13 Dekel et al. (2008) also theoretically argue that vote buying contributes to an inefficient outcome.

14 We are nevertheless reasonably confident that our measure of vote buying is a good proxy for vote buying in Taiwan because we quantify vote buying as the number of candidates in each county who have been prosecuted (as compared to convicted) for vote buying by the court. 


\section{References}

Aitchison, J. (1986). The Statistical Analysis of Compositional Data. London: Chapman and Hall. ISBN 9789401083249.

Becker, G. (1968). Crime and Punishment: An Economic Approach. Journal of Political Economy, 76(2), 169-217. DOI: 10.1086/259394.

Bellettini, G. (1998). Aggregate Uncertainty, Political Instability and Income Redistribution. European Journal of Political Economy, 14(1), 19-33. DOI: 10.1016/S0176-2680(97)00038-4.

Bosco, J. (1992). Taiwan Factions: Guanxi, Patronage, and the State in Local Politics. Ethnology, 31(2), 157-183. DOI: 10.2307/3773619.

Bosco, J. (1994). Faction versus Ideology: Mobilization Strategies in Taiwan's Elections. The China Quarterly, 137(1), 28-62. DOI: 10.1017/S0305741000034032.

Bratton, M. (2008). Vote Buying and Violence in Nigerian Election Campaigns. Electoral Studies, 27(4), 621-632. DOI: 10.1016/j.electstud.2008.04.013.

Brehm, J., Gates, S., Gomez, B. (1998). A Monte Carlo Comparison of Methods for Compositional Data Analysis. Paper presented at the 1998 meeting of the Society for Political Methodology.

Brehm, J., Gates, S., Gomez, B. (2003). Donut Shops, Speed Traps, and Paperwork: Supervision and the Allocation of Time to Bureaucratic Tasks, in Krause, G. A., Meier, K. J., eds., Politics, Policy and Organizations: Frontiers in the Scientific Study of Bureaucracy. Ann Arbor: The University of Michigan Press.

Brusco, V., Nazareno, M., Stokes, S. (2004). Vote Buying in Argentina. Latin American Research Review, 39(2), 66-88. DOI: 10.1353/lar.2004.0022.

Buis, M. L., Cox, N. J., Jenkins, S. P. (2006). DIRIFIT: Stata Module to Fit a Dirichlet Distribution.

Castanheira, M. (2003). Victory Margins and the Paradox of Voting. European Journal of Political Economy, 19(4), pp. 817-841. DOI: 10.1016/S0176-2680(03)00038-7.

Chu, Y., Diamond, L. (1999). Taiwan's 1998 Elections: Implications for Democratic Consolidation. Asian Survey, 39(5), pp. 808-822.

Colomer, J. M. (1991). Benefits and Costs of Voting. Electoral Studies, 10(4), pp. 313-325. DOI: 10.1016/0261-3794(91)90023-L.

Converse, P. E. (1972). Change in the American Electorate, in Campbell, A., Converse, P. E., eds., The Human Meaning of Social Change. New York: Russell Sage Foundation Press.

Cox, G. W., Munger, M. C. (1989). Closeness, Expenditures and Turnout in the 1982 US House Elections. American Political Science Review, 83(1), pp. 217-230.

Dekel, E., Jackson, M. O., Wolinsky, A. (2008). Vote Buying: General Elections. Journal of Political Economy, 116(2), pp. 351-380. DOI: 10.1086/587624.

Downs, A. (1957). An Economic Theory of Democracy. New York: Harper and Row.

Elinder, M. (2010). Local Economies and General Elections: The Influence of Municipal and Regional Economic Conditions on Voting in Sweden 1985-2002. European Journal of Political Economy, 26(2), 279-292. DOI: 10.1016/j.ejpoleco.2010.01.003.

Fisman, R., Gatti, R. (2002). Decentralization and Corruption: Evidence from U.S. Federal Transfer Programs. Public Choice, 113(1-2), pp. 25-35.

Feddersen, T. J., Pesendorfer, W. (1996). The Swing Voter's Curse. American Economic Review, 86(3), pp. 408-424. 
Frank, B., Pitlik, H., Wirth, S. (2004). Expert Opinion Leaders' Impact on Voter Turnout: The case of the Internet Chess Match Kasparov vs. World. European Journal of Political Economy, 20(3), pp. 619-635.

Fumagalli, E., Narciso, G. (2012). Political Institutions, Voter Turnout, and Policy Outcomes. European Journal of Political Economy, 28(2), pp. 162-173.

DOI: 10.1016/j.ejpoleco.2011.10.002.

Gersbach, H., Mühe, F. (2011). Vote-Buying and Growth. Macroeconomic Dynamics, 15(5), 656-680. DOI: 10.1017/S1365100510000246.

Geys, B. (2006). Explaining Voter Turnout: A Review of Aggregate-Level Research. Electoral Studies, 25(4), pp. 637-663. DOI: 10.1016/j.electstud.2005.09.002.

Geys, B., Heinemann, F., Kalb, A. (2010). Voter Involvement, Fiscal Autonomy and Public Sector Efficiency: Evidence from German Municipalities. European Journal of Political Economy, 26(2), pp. 265-278. DOI: 10.1016/j.ejpoleco.2009.11.002.

Glaeser, E. L., Saks, R. E. (2006). Corruption in America. Journal of Public Economics, 90(pp. 6-7, 1053-1072. DOI: 10.1016/j.jpubeco.2005.08.007.

Harbaugh, W. T. (1996). If People Vote because They Like to, Then Why Do So Many of Them Lie? Public Choice, 89(1-2), pp. 63-76. DOI: 10.1007/BF00114279.

Hasen, R. (2000). Vote Buying. California Law Review, 88(5), 1323-1371.

Haspel, M., Knotts, H. G. (2005). Location, Location: Precinct Placement and the Costs of Voting. The Journal of Politics, 67(2), pp. 560-573. DOI: 10.1111/j.1468-2508.2005.00329.x.

Hicken, A. (2007). How Do Rules and Institutions Encourage Vote Buying? in Schaffer, F. C., ed., Elections for Sale: The Causes, Consequences, and Reform of Vote Buying. Boulder, CO: Lynne Rienner.

Hillman, A. L. (2010). Expressive Behavior in Economics and Politics. European Journal of Political Economy, 26(4), pp. 403-418. DOI: 10.1016/j.ejpoleco.2010.06.004.

Hortala-Vallve, R., Esteve-Volart, B. (2011). Voter Turnout and Electoral Competition in a Multidimensional Policy Space. European Journal of Political Economy, 27(2), pp. 376-384. DOI: 10.1016/j.ejpoleco.2010.11.003.

Houser, D., Morton, R., Stratmann, T. (2011). Turned on or Turned out? Campaign Advertising, Information and Voting. European Journal of Political Economy, 27(4), pp. 708-727. DOI: 10.1016/j.ejpoleco.2011.05.003.

Khemani, S. (2004). Political Cycles in a Developing Economy: Effect of Elections in the Indian States. Journal of Development Economics, 73(1), pp. 125-154. DOI: 10.1016/j.jdeveco.2003.01.002.

Kostadinova, T. (2003). Voter Turnout Dynamics in Post-Communist Europe. European Journal of Political Research, 42(6), pp. 741-759. DOI: 10.1111/1475-6765.00102.

Lehoucq, F., Wall, D. (2004). Explaining Voter Turnout Rates in New Democracies: Guatemala. Electoral Studies, 23(3), pp. 485-500. DOI: 10.1016/S0261-3794(03)00055-6.

Lijphart, A. (1997). Unequal Participation: Democracy's Unresolved Dilemma. American Political Science Review, 91(1), pp. 1-14. DOI: 10.2307/2952255.

Matsusaka, J. G., Palda, F. (1993). The Downsian Voter Meets the Ecological Fallacy. Public Choice, 77(4), pp. 855-878. DOI: 10.1007/BF01047999.

Mikhailov, N., Niemi, R., Weimer, D. (2002). Application of Theil Group Logit Methods to District-Level Vote Shares: Tests of Prospective and Retrospective Voting in the 1991, 1993, and 1997 Polish Elections. Electoral Studies, 21(4), pp. 631-648.

DOI: 10.1016/S0261-3794(01)00040-3. 
Moon, E. (1997). Non-Transferable Vote Methods in Taiwan in 1996: Effects of an Electoral System. Asian Survey, 37(7), pp. 652-668. DOI: 10.2307/2645514.

Nathan, A. (1993). The Legislative Yuan Elections in Taiwan; Consequences of the Electoral System. Asian Survey, 33(4), pp. 424-438. DOI: 10.2307/2645107.

Niemi, R. G. (1976). Costs of Voting and Nonvoting. Public Choice, 27(1), 115-119. DOI: 10.1007/BF01718955.

Przeworski, A., Alvarez, M. E., Cheibub, J. A., Limongi, F. (2000). Democracy and Development: Political Institutions and Well-Being in the World, 1950-1990. UK: Cambridge University Press. ISBN 9780511804946.

Rigger, S. (2000). Machine Politics and Protracted Transition in Taiwan. Democratization, 7(3), pp. 135-152. DOI: 10.1080/13510340008403675.

Rigger, S. (2002). Weighting a Shadow: Toward a Technique for Estimating the Effects of Votebuying in Taiwan. Paper presented at the International Conference Trading Political Rights: The Comparative Politics of Vote Buying, Boston: MIT press.

Schaffer, F. C. (2002). What is Vote Buying? Paper Presented at the International Conference Trading Political Rights: The Comparative Politics of Vote Buying, Boston: MIT press.

Schaffer, F. C. (2004). Vote Buying in East Asia. Global Corruption Report 2004, Transparency International.

Sobbrio, F., Navarra, P. (2010). Electoral Participation and Communicative Voting in Europe. European Journal of Political Economy, 26(2), pp. 185-207.

DOI: 10.1016/j.ejpoleco.2010.01.002.

Theil, H. (1970). On the Estimation of Relationships Involving Qualitative Variables. American Journal of Sociology, 76(1), pp. 103-154. DOI: 10.1086/224909.

Tien, H., Chu, Y. (1996). Building Democracy in Taiwan. The China Quarterly, 148(4), pp. 1141-1170.

Verba, S., Nie, N. H. (1972). Participation in America: Political Democracy and Social Equality. New York: Harper and Row.

Vicente, P. (2007). Is Vote Buying Effective? Evidence from a Field Experiment in West Africa. Job Market Paper. UK: University of Oxford.

Vicente, P. (2010). Does oil corrupt? Evidence from a natural experiment in West Africa. Journal of Development Economics, 92(1), pp. 28-38. DOI: 10.1016/j.jdeveco.2009.01.005.

Wang, C., Kurzman, C. (2007). Dilemmas of Electoral Clientelism: Taiwan, 1993. International Political Science Review, 28(2), pp. 225-245. DOI: 10.1177/0192512107075408.

Wu, C., Huang, C. (2004). Politics and Judiciary Verdicts on Vote-Buying Litigation in Taiwan. Asian Survey, 44(5), pp. 755-770. DOI: 10.1525/as.2004.44.5.755.

York, A., Munroe, D. (2010). Urban Encroachment, Forest Regrowth and Land-Use Institutions: Does Zoning Matter? Land Use Policy, 27(2), pp. 471-479.

DOI: 10.1016/j.landusepol.2009.06.007. 